\title{
IL-8 mRNA expression by in situ hybridisation in human pituitary adenomas
}

\author{
M E R Suliman ${ }^{1}$, J A Royds ${ }^{4}$, L Baxter ${ }^{4}$, W R Timperley ${ }^{2}$, D R Cullen ${ }^{1}$ and T H Jones ${ }^{3}$ \\ Departments of ${ }^{1}$ Endocrinology and ${ }^{2}$ Neuropathology, Royal Hallamshire Hospital and ${ }^{3}$ Department of Human Metabolism and Clinical Biochemistry \\ and the ${ }^{4}$ Institute for Cancer Studies, University of Sheffield, Sheffield, UK \\ (Correspondence should be addressed to T H Jones, Department of Human Metabolism and Clinical Biochemistry, University of Sheffield Medical \\ School, Beech Hill Road, Sheffield S1O 2RX, UK)
}

\begin{abstract}
Several cytokines have been shown to be expressed in normal and adenomatous pituitary tissue. Recently, interleukin-8 (IL-8) mRNA was identified by reverse transcription (RT)-PCR in each of a series of 17 pituitary tumours examined. We have investigated further the presence of IL- 8 mRNA, using in situ hybridisation in two normal human anterior pituitary specimens and 25 human pituitary adenomas. IL-8 mRNA was not identified in either of the two normal pituitary specimens. Only three of the 25 adenomas were positive for IL- 8 mRNA. In these three tumours, which included two null cell adenomas and one gonadotrophinoma, the majority of tumour cells ( $>90 \%)$ were positive for IL-8 mRNA. The remaining 22 adenomas were completely negative. There was no difference in tumour size or type between the IL-8 positive and the IL- 8 negative tumours, and immunocytochemistry for von Willebrandt factor showed that the two groups were also similar in their degree of vascularisation.

In conclusion, IL- 8 mRNA was found in $12 \%$ of pituitary adenomas studied and was histologically identified within the tumour cells. In situ hybridisation is a more appropriate technique for assessing cytokine mRNA production by human pituitary tumours because RT-PCR may be too sensitive, identifying very small, possibly pathologically insignificant, quantities of mRNA that could be produced by supporting cells such as fibroblasts, endothelial cells or macrophages.
\end{abstract}

European Journal of Endocrinology 140 155-158

\section{Introduction}

Cytokines are multi-functional peptides that are now known to be produced by a number of normal and neoplastic cells, apart from those of the immune system. Cytokines may act either systemically or locally within tissues as paracrine agents. Several cytokines have been shown to be produced by human pituitary adenomas and may have a part to play in the pathogenesis of these tumours $(1,2)$. Recently, expression of mRNA transcripts for several cytokines has been demonstrated in human pituitary tumours by reverse transcription (RT)PCR (3, 4). These include the following cytokines: interleukins (IL)- $1 \alpha,-1 \beta,-2,-4,-6,-8,-10,-12,-14,-15$, -16 and -17 , tumour necrosis factors $\alpha$ and $\beta$, and transforming growth factor $\beta$. In addition, IL-1 receptor antagonist mRNA has been demonstrated in human corticotrophinomas, somatotrophinomas and nonfunctioning adenomas (5). The technique of RT-PCR, however, does not define the cells of origin, particularly whether or not the source is the neoplastic cell or other nonadenomatous cells such as fibroblasts, macrophages or endothelial cells. Immunoreactive and bioreactive
IL-6 is known to be secreted by between 50 and $60 \%$ of pituitary adenomas, independent of the tumour type (6). Moreover, the IL-6 mRNA has been demonstrated, by in situ hybridisation, to be present in the adenomatous cells of the pituitary tumours (6).

IL-8 is an inflammatory cytokine that was originally identified on the basis of its chemotactic activity (7). It was found initially in inflammatory cells, but has since been identified in some normal cells - for example thyrocytes - and in several neoplastic cells, including those of thyroid carcinoma, transitional cell carcinoma, squamous cell carcinoma, B-cell chronic lymphocytic leukaemia and melanoma (7). The functional role, if any, of IL- 8 in these tumours has not been established, but there is some evidence that its production in the microenvironment of tumour cells in vivo could influence the immune response to the tumour by modulating the recruitment of neutrophils at the site of the tumour (7). Moreover, it has been suggested that IL-8 may act as an autocrine growth factor in melanoma cell lines (8), or may have a potent angiogenic effect similar to that of basic fibroblast growth factor (9). 
IL-8 mRNA has been found consistently, by the very sensitive method of RT-PCR, in all pituitary adenomas in one study (3). A high number (35) of PCR cycles was required to demonstrate cytokine expression in pituitary adenomas, suggesting that a low number of mRNA transcripts were actually present. Contaminating nontumour cells could potentially have contributed to the cytokine profiles found in that particular study. We have therefore used in situ hybridisation to look for IL-8 mRNA in pituitary adenomas. The technique of in situ hybridisation does allow the identification of the source of the mRNA using histological criteria (10).

Because IL- 8 could potentially be involved in tumour angiogenesis, we performed immunocytochemistry for von Willebrandt factor (vWF), which assesses the degree of vascularisation of the tumours by identifying endothelial cells.

\section{Materials and methods}

Archival material from 25 pituitary adenomas removed transsphenoidally was used for this study. The tumours included ten null cell adenomas, five somatotrophinomas, five prolactinomas, four mixed growth hormone/ prolactin adenomas and one gonadotrophinoma. Table 1 gives details of the patients and tumours. Two sections of normal anterior pituitary tissues were also studied.

\section{In situ hybridisation for IL-8 mRNA}

After deparaffinization and rehydration, sections were digested at $4{ }^{\circ} \mathrm{C}$ with proteinase $\mathrm{K}$ at a concentration of $10 \mu \mathrm{g} / \mathrm{ml}$ in Tris-HCl buffer for $10 \mathrm{~min}$, followed by post-fixation in $0.4 \%$ paraformaldehyde in PBS, at $4{ }^{\circ} \mathrm{C}$. Sections were then incubated in prehybridisation buffer for $60 \mathrm{~min}$ at $37^{\circ} \mathrm{C}$. The IL- 8 antisense probe used was a cocktail of oligonucleotides labelled with fluorescein (R \& D Systems Europe, Abingdon, Oxon, UK). Slides were hybridised to the probe diluted $1: 100$ in the buffer overnight at $37^{\circ} \mathrm{C}$, followed by washing in $4 \times \mathrm{SSC}$ at $37^{\circ} \mathrm{C}$. After preincubation with $20 \%$ normal sheep serum, specifically bound probe was detected using antifluorescein-AP Fab fragments (Boehringer Mannheim, Lewes, UK) and, after a further wash with buffer, Nitra blue tetrazolium/5 bromo-4-chloro-3-indolyl-phosphate was used as chromogen. An inflamed appendix was used as a positive control and omission of the probe was used as negative control.

\section{Immunocytochemistry for von Willebrandt factor}

For the immunocytochemical detection of $\mathrm{vWF}$, the avidin-biotin-peroxidase system (ABC) was used on formalin-fixed paraffin-embedded tissue sections. Briefly, the slides were dewaxed, rehydrated and treated

Table 1 Details of 25 patients with pituitary adenomas tested for IL-8 mRNA by in situ hybridisation (ISH).

\begin{tabular}{|c|c|c|c|c|c|c|}
\hline Patient no. & $\begin{array}{c}\text { Age } \\
\text { (years) }\end{array}$ & Sex & Tumour size & Clinical presentation & Immunocytochemistry & IL-8 ISH \\
\hline 1 & 62 & $M$ & macro with sse & Prolactinoma & PRL & Negative \\
\hline 2 & 50 & $M$ & macro with sph se & Acromegaly & $\mathrm{GH}$ & Negative \\
\hline 3 & 55 & $\mathrm{~F}$ & large cystic macro & Non-functioning adenoma & Null & Negative \\
\hline 4 & 66 & $M$ & macro with sse & Non-functioning adenoma & Null & Negative \\
\hline 5 & 81 & $\mathrm{~F}$ & macro & Non-functioning adenoma & Null & Negative \\
\hline 6 & 44 & $\mathrm{~F}$ & macro with sse & Acromegaly & $\mathrm{GH}$ & Negative \\
\hline 7 & 32 & $M$ & large macro & Prolactinoma & PRL & Negative \\
\hline 8 & 63 & $\mathrm{~F}$ & macro with no sse & Acromegaly & PRL & Negative \\
\hline 9 & 35 & $M$ & macro with pse & Acromegaly & $\mathrm{GH} / \mathrm{PRL}$ & Negative \\
\hline 10 & 50 & $\mathrm{M}$ & macro with sse and pse & Acromegaly & $\mathrm{GH}$ & Negative \\
\hline 11 & 42 & $\mathrm{M}$ & macro with sse & Acromegaly & $\mathrm{GH}$ & Negative \\
\hline 12 & 43 & $\mathrm{~F}$ & macro with sse & Acromegaly & $\mathrm{GH} / \mathrm{PRL}$ & Negative \\
\hline 13 & 55 & $M$ & large cystic macro & Non-functioning adenoma & Null & Negative \\
\hline 14 & 74 & $\mathrm{M}$ & macro with sse & Non-functioning adenoma & Null & Negative \\
\hline 15 & 46 & $\mathrm{M}$ & macro with sse and cse & Prolactinoma & PRL & Negative \\
\hline 16 & 47 & $\mathrm{~F}$ & large cystic macro & Prolactinoma & Null & Negative \\
\hline 17 & 52 & $\mathrm{~F}$ & macro with sse & Non-functioning adenoma & Null & Positive \\
\hline 18 & 60 & $M$ & macro with sse & Non-functioning adenoma & GN & Positive \\
\hline 19 & 38 & $\mathrm{M}$ & 7-mm micro & Acromegaly & $\mathrm{GH} / \mathrm{PRL}$ & Negative \\
\hline 20 & 46 & $\mathrm{~F}$ & macro with sse & Non-functioning adenoma & Null & Negative \\
\hline 21 & 74 & $M$ & macro with sse & Non-functioning adenoma & Null & Positive \\
\hline 22 & 61 & $\mathrm{~F}$ & macro & Acromegaly & $\mathrm{GH} / \mathrm{PRL}$ & Negative \\
\hline 23 & 61 & $M$ & macro with sse & Prolactinoma & PRL & Negative \\
\hline 24 & 31 & $\mathrm{~F}$ & macro & Prolactinoma & PRL & Negative \\
\hline 25 & 54 & $M$ & huge macro with sse & Non-functioning adenoma & Null & Negative \\
\hline
\end{tabular}

macro, macroadenoma (i.e. >10 mm diameter); micro, microadenoma (i.e. <10 mm diameter); sse, suprasellar extension; sph. se, sphenoid sinus extension; pse, parasellar extension; cse, cavernous sinus extension; PRL, prolactinoma; GH, growth hormone-producing adenoma; GN, gonadotrophinoma. 
with 3\% hydrogen peroxide in methanol to inhibit endogenous peroxidase activity. Antigen retrieval was performed by incubation of the slides in $0.1 \%$ trypsin solution for $10 \mathrm{~min}$. After the slides had been washed in Tris-buffered saline (TBS), normal goat serum was added, and after 15 min this was washed off by TBS and the slides were incubated for $30 \mathrm{~min}$ with anti-vWF rabbit polyclonal antibody (Dako, High Wycombe, UK) at a dilution of $1: 400$. After secondary biotinylated anti-goat antibody and $\mathrm{ABC}$ complex had been added, the antigen-antibody binding sites were visualised using the chromogen, diaminobenzidine. A colonic carcinoma section was used as a positive control, and omission of the antibody as a negative control.

\section{Results}

IL-8 mRNA was not identified in either of the two normal pituitary tissue specimens. It was identified in three pituitary adenomas, of which two were null-cell adenomas and the third the gonadotrophinoma. In each of these tumours, more than $90 \%$ of cells were clearly positive for IL-8 mRNA (Fig. 1). In the remaining 22 adenomas, no IL- 8 mRNA was identified (Table 1 ). The three positive adenoma sections were examined by a pituitary neuropathologist and the IL-8 mRNA was localised to the adenoma cells. There was no evidence of increased numbers of inflammatory cells in the IL-8 positive sections examined, compared with the IL-8 negative ones.

Immunocytochemistry for vWF was performed on the three positive tumours and on five of the negative ones. Endothelial cells were identified by this technique in all eight tumours and, although there was variability in the degree of vascularisation between the different tumours and in different areas of the same tumour, there was no obvious difference in the degree of vascularisation between the IL- 8 positive and the IL- 8 negative tumours.

\section{Discussion}

This study has demonstrated, by in situ hybridisation, that IL-8 mRNA is present in the neoplastic cells in only a small proportion ( $12 \%$ in this study) of human pituitary adenomas. This finding is in contrast with the identification of IL- 8 mRNA by RT-PCR being found in $100 \%$ of pituitary adenomas previously examined (3). In situ hybridisation appears to be a more appropriate investigation for the presence of cytokine mRNA transcripts in pituitary adenomas, as it is more likely to identify biologically significant expression (11). The high sensitivity of RT-PCR is likely to identify the negligible quantities of mRNA that may be present in non-neoplastic cells such as fibroblasts or occasional inflammatory cells.

In the three positive tumours, the IL- 8 mRNA was identified predominantly within adenoma cells (Fig. 1).
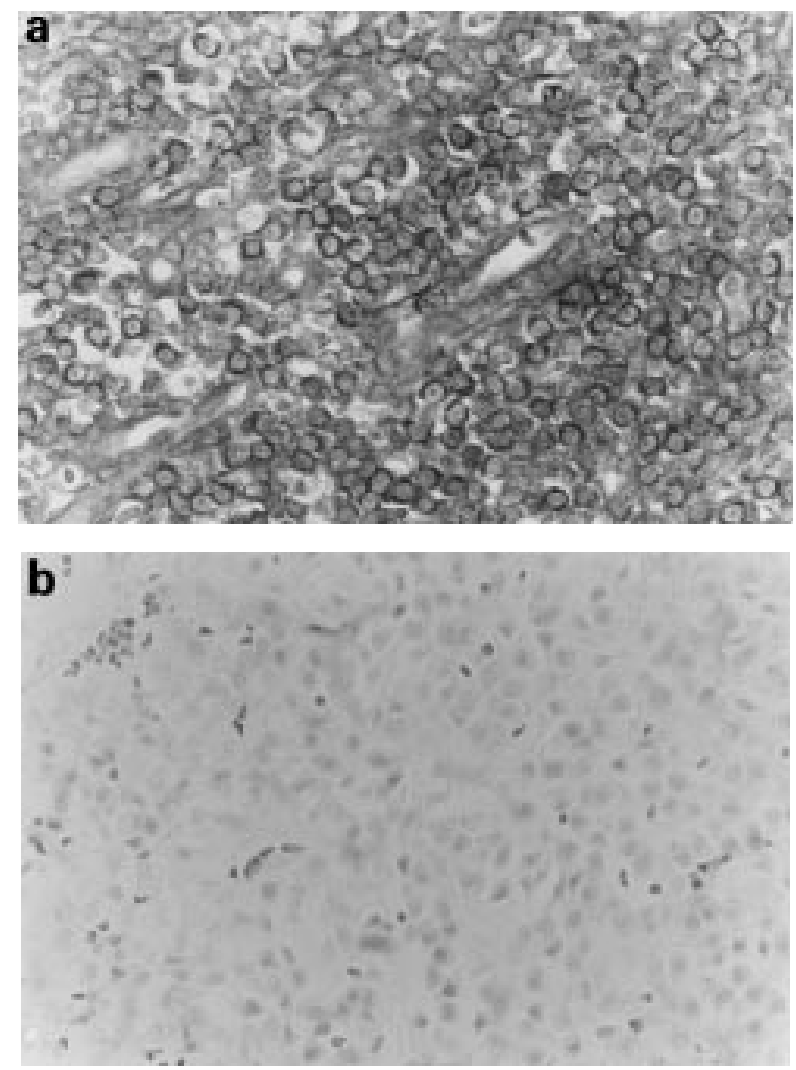

Figure 1 (a) In situ hybridisation for IL-8 mRNA in a pituitary adenoma (patient No. 21 in Table 1), showing positive cytoplasmic staining (blue colour) for IL-8 mRNA in the majority of adenoma cells. (b) Negative control in the same adenoma with omission of the probe, showing only the green counterstain of the nucleus. Original magnifications, $\times 1200$.

On histological examination, none of the three IL-8 mRNA positive adenomas demonstrated aggressive or any other features pathologically or clinically different from those tumours that were negative (Table 1).

For a number of cytokines, mRNAs or synthesis and secretion of the protein, or both, have been demonstrated in human pituitary adenomas $(1,2)$. The expression of different cytokines, as for many other agents such as growth factors, varies between different types of pituitary adenomas. The pathophysiological role of the cytokines in pituitary adenomas is not apparent; however, cytokines in general have many actions, which include stimulation or inhibition of growth and proliferation, cellular differentiation, apoptosis and hormone secretion. In a minority of primary cultures of human pituitary adenomas, IL- 6 in high concentration can have diverse effects on $\left[{ }^{3} \mathrm{H}\right]$ thymidine uptake, with either stimulation or inhibition having been observed (12). A role for IL-8 in pituitary adenomas is not yet clear, as its main known function is as a neutrophil chemoattractant. Neutrophils are not found in any significant numbers within pituitary 
adenomas and, in the tumours studied here, there was no increased number of polymorphonuclear cells in the positive adenomas, compared with those that were negative. IL- 8 is known to be produced by monocytes, macrophages, T-lymphocytes, neutrophils, fibroblasts, endothelial cells and mesothelial cells (7). The production of IL-8 in the pituitary tumour microenvironment could potentially influence the immune response to the neoplastic cells by modulating the recruitment of neutrophils at the site of the tumour (7). Alternatively, IL- 8 could have been produced by the adenoma cells as a response to hypoxic/anoxic insults on these cells after they had outgrown their rich blood supply, as has previously been shown for gliobastoma cells (13), suggesting a role for this cytokine in the promotion of angiogenesis. In support of this possibility is the fact that the three positive tumours were all large macroadenomas with suprasellar extension; however, they were not significantly different from the other 22 negative adenomas in size or type (Table 1). To assess further whether the IL-8 produced by the pituitary tumours was involved in the angiogenic process we performed immunocytochemistry for $\mathrm{vWF}$ on the three positive and on five negative tumours. Endothelial cells were identified by this technique in all eight tumours and, although different areas in the tumours showed variability in the degree of vascularisation, there was no difference between the IL- 8 positive and the IL- 8 negative tumours. This suggests that IL-8 in pituitary tumours is probably not involved in the stimulation of angiogenesis although the numbers examined were small.

No direct effects of IL-8 on pituitary hormone secretion have been reported, however, the cytokineinduced neutrophil chemoattractant, CINC/gro, a member of the IL- 8 family, has been identified immunocytochemically and by Western blot analysis in the normal rat anterior pituitary (14). This cytokine has been shown to stimulate the production of prolactin and to inhibit secretion of luteinizing hormone and folliclestimulating hormone by rat anterior pituitary cells (15).

The role of cytokines produced by human pituitary adenomas is not yet apparent. One hypothesis is that the production of different cytokine profiles by pituitary adenomas is an inadequate alarm signal by the abnormal cell to stimulate self destruction by apoptosis or to induce an immune response against itself. Other potential roles could be an involvement in modulation of hormone secretion or adenoma growth, through their effects on angiogenesis or other mechanisms.

In conclusion, IL- 8 mRNA is expressed profusely by a minority of human pituitary adenomas. This study does show that in situ hybridisation may be a more appropriate investigation for the significant presence of cytokine mRNA transcripts in human pituitary tissue. The reason for IL-8 mRNA production in these tumours is as yet not clear, and requires further investigation.

\section{Acknowledgements}

J A R is supported by the Yorkshire Cancer Research. We are grateful to Tracy Sanderson from the Department of Pathology, Royal Hallamshire Hospital for her help with immunocytochemistry for vWF.

\section{References}

1 Renner U, Pagotto U, Artz E \& Stalla GK. Autocrine and paracrine roles of polypeptide growth factors, cytokines and vasogenic substances in normal and tumorous pituitary function and growth: a review. European Journal of Endocrinology 1996135 515-532.

2 Ray D \& Melmed S. Pituitary cytokine and growth factor expression and action. Endocrine Reviews 199718 206-228.

3 Green VL, Atkin SL, Speirs V, Jeffreys RV, Landolt AM, Mathews B, Hipkin L \& White MC. Cytokine expression in human anterior pituitary adenomas. Clinical Endocrinology 199645 179-185.

4 Green VL, Speirs V, Jeffreys RV, Foy P, Mathews, B Landolt AM \& Atkin SL. Expression of cytokines IL10 and IL12-17 in human anterior pituitary adenomas. Journal of Endocrinology 1998156 (Suppl) 204.

5 Sauer J, Artz E, Hopfner U, Gumprecht H \& Stalla GK. Expression of interleukin-1 receptor antagonist in human pituitary adenomas in vitro. Journal of Clinical Endocrinology and Metabolism 1994 79 1857-1863.

6 Jones TH, Daniels M, James RA, Justice SK, McCorkle R, Price A, Kendall-Taylor P \& Weetman AP. Production of bioactive and immunoreactive interleukin- 6 and expression of IL- 6 mRNA by human pituitary adenomas. Journal of Clinical Endocrinology and Metabolism 199478 180-187.

7 Hebert CA \& Baker JB. Interleukin-8: a review. Cancer Investigation $199311743-750$.

8 Forster E, Kirnbauer R \& Urbanski A. Human melanoma cells produce interleukin- 8 which functions as an autocrine growth factor. Clinical Research 199139 517A.

9 Koch A, Polverini P \& Kunkel S. Interleukin-8 as a macrophagederived mediator of angiogenesis. Science 1992258 1798-1801.

10 Hoeffaker S, Boersma WJA \& Claassen E. Detection of human cytokines in situ using antibody and probe based methods. Journal of Immunological Methods 1995185 149-175.

11 Lloyd RV, Jin L \& Chandler WF. In situ hybridisation studies in human pituitaries. In Pituitary Adenomas edn 1, ch 4, pp 47-58. Ed A Landolt. New York: Churchill Livingstone, 1996.

12 Jones TH, Suliman M \& Justice S. Effects of interleukin-6 on thymidine uptake in human pituitary adenoma cells. Abstracts of the IV European Congress of Endocrinology, Seville, Spain, 1998, OR 9-6. Bristol:BioScientifica.

13 Desbaillets I, Diserens AC, deTribolet N, Hamou MF \& VanMeir EG. Upregulation of interleukin 8 by oxygen-deprived cells in glioblastoma suggests a role in leukocyte activation, chemotaxis and angiogenesis. Journal of Experimental Medicine 1997186 $1202-1212$

14 Koike K, Sakamoto Y, Sawada T, Ohimichi M, Kanda Y, Nohara A, Hirota K, Kiyama H \& Miyake A. The production of CINC/gro, a member of the interleukin-8 family, in rat anterior pituitary gland. Biochemical and Biophysical Research Communications 1994 202 161-167.

15 Sawada T, Koike K, Kanda Y, Sakamoto Y, Nohara A, Ohmichi M, Hirota K \& Miyake A. In vitro effects of CINC/gro, a member of the interleukin-8 family, on hormone secretion by rat anterior pituitary cells. Biochemical and Biophysical Research Communications 1994202 155-160.

Received 6 November 1998

Accepted 9 November 1998 